\title{
PNEUMOCONIOSIS OF COAL-MINERS IN THREE NORTHUMBRIAN COLLIERIES
}

\author{
BY \\ R. I. MCCALLUM and D. J. NEWELL \\ From the Nuffield Department of Industrial Health, King's College, Newcastle upon Tyne, University of Durham
}

(RECEIVED FOR PUBLICATION OCTOBER 23, 1957)

Radiological pneumoconiosis is common amongst coal-miners in County Durham, and in four collieries about $22 \%$ of men at work above and below ground had fairly well-marked lung changes of category 2 or more (McCallum and Browne, 1955).

There are no reliable prevalence data for pneumoconiosis of coal-miners in the adjacent coalfield of Northumberland, but its mines are thought to produce little pneumoconiosis compared with those of Durham and the rest of the country. In the Outpatient Clinic of the Nuffield Department of Industrial Health relatively few men with pneumoconiosis of coal-miners are seen from Northumberland, the majority being Durham miners. Practically the only information available is the number of men certified under the various pneumoconiosis compensation acts since 1933 when faceworkers in mines were first included (Table 1). During the 10 years following 1933 Hume (personal communication) as a medical referee saw 100 men from Durham pits and only 15 from Northumberland. The figures for South Wales for the period 1933 to mid-1948 are taken from Hugh-Jones and Fletcher (1951).

Between 1943 and 1948, the worst three pits in Northumberland had only nine, nine, and four men certified respectively (Hume), and the records of the National Union of Mineworkers (Northumberland) show 41 men certified and six deaths from Northumberland compared with the Durham area of the N.U.M. which had 322 men certified and 46 deaths in the same period. There are about two and a half times as many men employed at coalmines in Durham compared with Northumberland but the certification rate per man in Durham is two to three times greater. Data published by the Ministry of Fuel and Power (1950-1954) of men certified by the Pneumoconiosis Medical Panel show on the average for $1951-1953$ about 1.6 per 1,000 in Northumberland and 4 per 1,000 in Durham. In these three years, most Northumbrian miners certified by pneumoconiosis boards were over 45 years of age, only two men being less than 35 years of age, and the majority of assessments for disability were under $40 \%$ loss of faculty.

Until 1942 the number of men certified was not more than three a year from Northumberland and 21 a year from Durham, but since 1948 the number of men certified by the Pneumoconiosis Panel has increased sharply, following the new National Insurance (Industrial Injuries) Act.

TABLE 1

NUMBER OF MEN CERTIFIED BY SILICOSIS OR PNEUMOCONIOSIS BOARDS IN DURHAM AND NORTHUMBERLAND WITH COMPARATIVE DATA FOR SOUTH WESTERN DIVISION

\begin{tabular}{|c|c|c|c|c|c|c|}
\hline \multirow{2}{*}{ Period } & \multicolumn{2}{|c|}{$\begin{array}{c}\text { Northumberland } \\
\text { (Approximately } 40,000 \text { Employed) }\end{array}$} & \multicolumn{2}{|c|}{$\begin{array}{c}\text { Durham } \\
\text { (Approximately } 100,000 \text { Employed) }\end{array}$} & \multicolumn{2}{|c|}{$\begin{array}{c}\text { South Western Division } \\
\text { (Approximately } 107,000 \text { Employed) }\end{array}$} \\
\hline & No. of Men & Per 1,000 Employed & No. of Men & Per 1,000 Employed & No. of Men & Per 1,000 Employed \\
\hline $\begin{array}{c}1933-42 \\
30.6 .43 \text { to } 5.7 .48 \\
5.7 .48 \text { to } 25.3 .50 \\
27.3 .50 \text { to } 30.12 .50 \\
1951\end{array}$ & $\begin{array}{l}15 \\
41^{*} \\
36 \\
18 \\
70\end{array}$ & $\begin{array}{l}0 \\
1 \\
1 \\
0 \\
2\end{array}$ & $\begin{array}{l}100 \\
322 \dagger \\
338 \\
176 \\
395\end{array}$ & $\begin{array}{l}1 \\
3 \\
3 \\
2 \\
4\end{array}$ & $\begin{array}{r}3,540 \\
15,080 \\
5,638 \\
1,511 \\
1,221\end{array}$ & $\begin{array}{r}33 \\
140 \\
53 \\
14 \\
11\end{array}$ \\
\hline 1952 & 31 & 1 & 390 & 4 & 1,036 & 10 \\
\hline 1953 & 89 & 2 & 435 & 4 & 1,061 & 10 \\
\hline 1954 & 94 & 2 & 616 & 6 & 921 & 9 \\
\hline
\end{tabular}




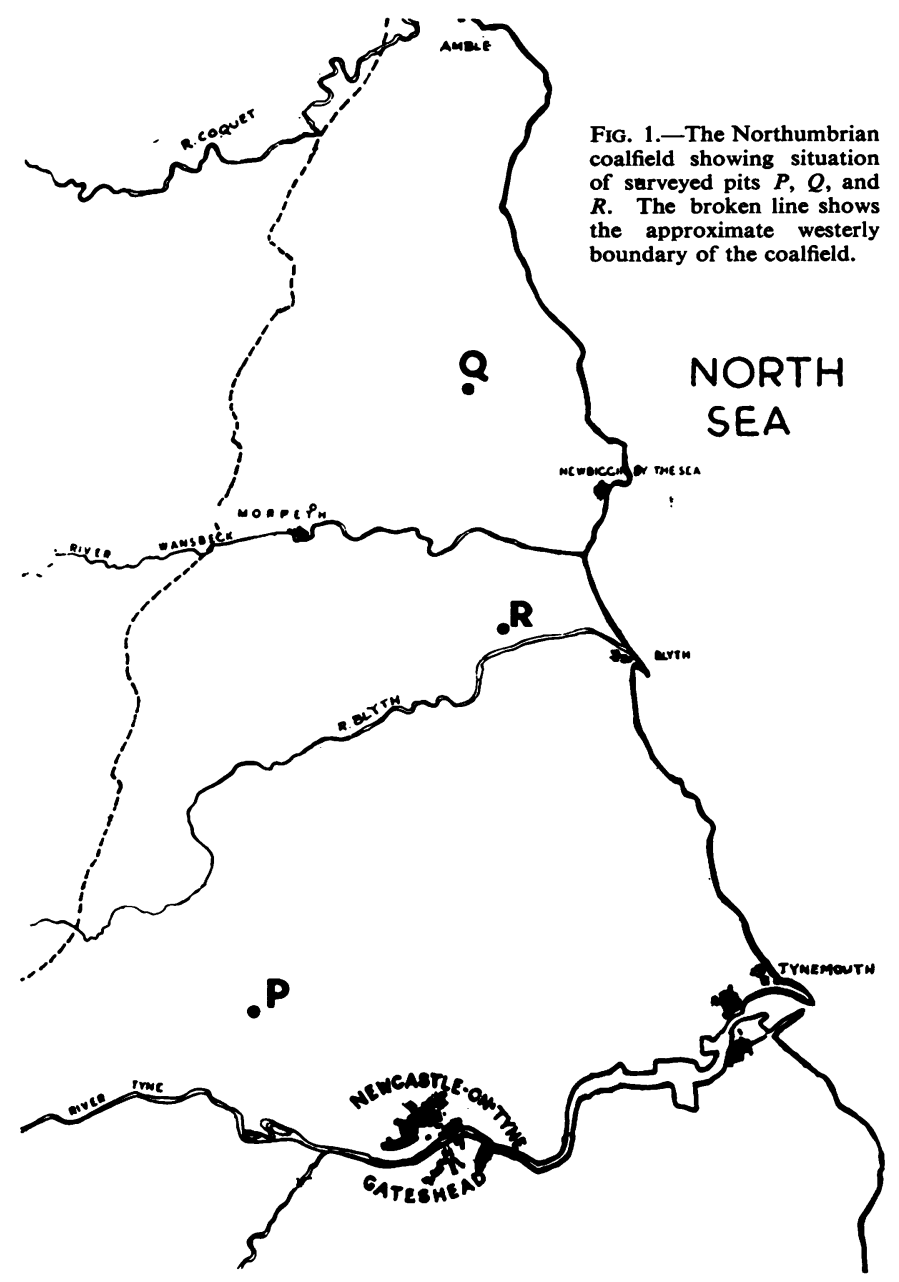

chosen on a basis of geography, size, and type. They were situated in the upper, middle, and lower parts of the coalfield which is roughly wedgeshaped with its apex pointing north (Fig. 1). The largest pit had 1,254 men and the smallest 1,072 and all three were considered, in general, typical Northumbrian pits in working methods and coal seams. They are now fully mechanized and coal is won entirely mechanically, either by arcwall cutting as in Pit $R$ or by long-wall cutting as in $P$ and $Q$. For the fiveyear period before 1948 the number of men certified (total and partial) from Pits $P, Q$, and $R$ was one, three, and two respectively, and from 1949 to the end of 1952, four, four, and three respectively.

Organization of Survey and Radiology.-The organization of the survey, the method of reading radiographs, and the follow-up of those who did not attend were similar to those described in a survey of four Durham collieries (McCallum and Browne, 1955). Radiographs were categorized according to the proposed International Classification of Pneumoconiosis (Cochrane, Davies, and Fletcher, 1951; International Labour Office, 1953) by three viewers working separately and the median of their readings was taken as the final category. Where disagreement was marked additional readings were made. The length of time spent by the radiography unit at each colliery

\section{Present Survey}

A survey comparable to that already made in Durham was carried out in three Northumbrian pits in 1953/54 to determine the prevalence of radiological abnormality. Only large (12 in. $\times$ 15 in.) films were used and these were taken by a mobile mass radiography unit provided by the Newcastle Regional Hospital Board.

It must be emphasized that any estimate of the prevalence of pneumoconiosis relates to dusty conditions existing during the 30-40 years preceding the investigation and that no precise information about the past environment exists nor are any dust counts available even from the period immediately before the survey.

Choice of Pits.-Three pits $(P, Q$, and $R)$ were during this survey was about two full weeks.

\section{Prevalence}

Eighty-five per cent of 3,400 men at work above and below ground had a chest radiograph at these three collieries (Table 2). About a quarter $(24 \cdot 8 \%)$

TABLE 2

NUMBER* AND PERCENTAGE OF MEN RADIOGRAPHED

\begin{tabular}{c|c|c|c|c|c}
\hline \multirow{2}{*}{ Colliery } & $\begin{array}{c}\text { Total Number } \\
\text { of Men from } \\
\text { Pay Record }\end{array}$ & \multicolumn{2}{|c|}{$\begin{array}{c}\text { Men } \\
\text { Radiographed }\end{array}$} & \multicolumn{2}{|c}{$\begin{array}{c}\text { Men not } \\
\text { Radiographed }\end{array}$} \\
\cline { 3 - 6 } & & No. & $\%$ & No. & $\%$ \\
\hline$P$ & 1,072 & 930 & $86 \cdot 8$ & 142 & $13 \cdot 2$ \\
$Q$ & 1,254 & 1,087 & 86.7 & 167 & 13.3 \\
$R$ & 1,074 & 881 & $82 \cdot 0$ & 193 & $18 \cdot 0$ \\
\hline Total .. & 3,400 & 2,898 & $85 \cdot 2$ & 502 & $14 \cdot 8$ \\
\hline
\end{tabular}

*The total number of men employed at the colliery was obtained from the pay records at the time of the survey. 
TABLE 3

PERCENTAGE OF EXAMINED MEN WITH PNEUMOCONIOSIS IN EACH COLLIERY BY CATEGORIES

\begin{tabular}{|c|c|c|c|c|c|c|c|c|}
\hline \multirow{3}{*}{ Category } & \multicolumn{8}{|c|}{ Colliery } \\
\hline & \multicolumn{2}{|c|}{$P$} & \multicolumn{2}{|c|}{$Q$} & \multicolumn{2}{|c|}{$\boldsymbol{R}$} & \multicolumn{2}{|c|}{ Total } \\
\hline & No. & $\%$ & No. & $\%$ & No. & $\%$ & No. & $\%$ \\
\hline $\begin{array}{c}1 \\
2 \\
3 \\
\text { P.M.F. }\end{array}$ & $\begin{array}{r}113 \\
87 \\
15 \\
5\end{array}$ & $\begin{array}{r}12.2 \\
9.4 \\
1.6 \\
0.5\end{array}$ & $\begin{array}{r}177 \\
82 \\
26 \\
5\end{array}$ & $\begin{array}{r}16.3 \\
7.5 \\
2.4 \\
0.5\end{array}$ & $\begin{array}{r}107 \\
72 \\
26 \\
3\end{array}$ & $\begin{array}{r}12.1 \\
8.2 \\
3.0 \\
0.3\end{array}$ & $\begin{array}{r}397 \\
241 \\
67 \\
13\end{array}$ & $\begin{array}{r}13 \cdot 7 \\
8 \cdot 3 \\
2 \cdot 3 \\
0 \cdot 4\end{array}$ \\
\hline Total & 220 & $23 \cdot 7$ & 290 & 26.7 & 208 & 23.6 & 718 & $24 \cdot 8$ \\
\hline
\end{tabular}

of the 2,898 men radiographed have pneumoconiosis of Category 1 or more (Table 3 ) and $11 \%$ pneumoconiosis of Category 2 or more. There are no marked differences between the proportion of each category in the three pits with the exception of $Q$, which appears to have an excess in Category 1, but this difference is not statistically significant and could have arisen by chance.

When the ages of the men radiographed are considered (Table 4), $P$ has relatively more men over 46 years of age; $Q$ has more men in the 26-35 years and $26-45$ years groups; $R$ has $48.5 \%$ of the $15-25$ years group and a smaller proportion than the other two pits in the three older groups.

TABLE 4

NUMBER AND PERCENTAGE OF MEN RADIOGRAPHED IN EACH COLLIERY BY AGE

\begin{tabular}{|c|c|c|c|c|c|c|c|c|}
\hline \multirow{3}{*}{ Age } & \multicolumn{6}{|c|}{ Colliery } & \multirow{2}{*}{\multicolumn{2}{|c|}{ Total }} \\
\hline & \multicolumn{2}{|c|}{$P$} & \multicolumn{2}{|c|}{$Q$} & \multicolumn{2}{|c|}{$\boldsymbol{R}$} & & \\
\hline & No. & $\%$ & No. & $\%$ & No. & $\%$ & No. & $\%$ \\
\hline $\begin{array}{l}15-25 \\
26-35 \\
36-45 \\
46-55 \\
56+\end{array}$ & \begin{tabular}{|r}
99 \\
161 \\
209 \\
242 \\
219
\end{tabular} & $\begin{array}{l}22 \cdot 6 \\
24 \cdot 5 \\
32 \cdot 6 \\
37 \cdot 2 \\
43 \cdot 0\end{array}$ & $\begin{array}{l}127 \\
297 \\
261 \\
240 \\
162\end{array}$ & $\begin{array}{l}28.9 \\
45.1 \\
40.7 \\
36.9 \\
31.8\end{array}$ & $\begin{array}{l}213 \\
200 \\
172 \\
168 \\
128\end{array}$ & $\begin{array}{l}48 \cdot 5 \\
30 \cdot 4 \\
26 \cdot 8 \\
25 \cdot 8 \\
25 \cdot 1\end{array}$ & $\begin{array}{l}439 \\
658 \\
642 \\
650 \\
509\end{array}$ & $\begin{array}{r}100.0 \\
100.0 \\
100.1 \\
99.9 \\
99.9\end{array}$ \\
\hline Total & 930 & $32 \cdot 1$ & 1,087 & 37.5 & 881 & $30 \cdot 4$ & 2,898 & $100 \cdot 0$ \\
\hline
\end{tabular}

When the amount of pneumoconiosis is related to the age of the men in 10-year groups (Table 5), there are only 60 men out of 1,097 under 35 years who have any pneumoconiosis at all and most of the
TABLE 6

MEN WITH PNEUMOCONIOSIS (CATEGORY 1 AND ABOVE) IN EACH COLLIERY BY AGE AS A PERCENTAGE OF ALL MEN RADIOGRAPHED IN EACH AGE GROUP

\begin{tabular}{|c|c|c|c|c|c|c|c|c|}
\hline \multirow{3}{*}{ Age } & \multicolumn{6}{|c|}{ Colliery } & \multirow{2}{*}{\multicolumn{2}{|c|}{ Tot }} \\
\hline & \multicolumn{2}{|c|}{$P$} & \multicolumn{2}{|c|}{$Q$} & \multicolumn{2}{|c|}{$\boldsymbol{R}$} & & \\
\hline & No. & $\%$ & No. & $\%$ & No. & $\%$ & No. & $\%$ \\
\hline $\begin{array}{l}15-25 \\
26-35 \\
36-45 \\
46-55 \\
56+\end{array}$ & $\begin{array}{r}\overline{5} \\
33 \\
82 \\
100\end{array}$ & $\begin{array}{r}\overline{3.1} \\
15.8 \\
33.9 \\
45.7\end{array}$ & $\begin{array}{r}3 \\
44 \\
64 \\
98 \\
81\end{array}$ & $\begin{array}{r}2.4 \\
14.8 \\
24.5 \\
40.8 \\
50.0\end{array}$ & $\begin{array}{r}1 \\
7 \\
48 \\
79 \\
73\end{array}$ & $\begin{array}{r}0.5 \\
3.5 \\
27.9 \\
47.0 \\
57.0\end{array}$ & $\begin{array}{r}4 \\
56 \\
145 \\
259 \\
254\end{array}$ & $\begin{array}{r}0.9 \\
8.5 \\
22.6 \\
39.8 \\
49.9\end{array}$ \\
\hline
\end{tabular}

men with Category 3 pneumoconiosis are over 45 years of age. In each category of pneumoconiosis the proportion of men affected increased systematically with advancing age, and there is no tendency to level out after a particular age. The same trend is seen in each colliery separately (Table 6), but colliery $Q$ has four to five times the proportion of men with pneumoconiosis in the 26-35 years age group compared with $P$ and $R$. There is a higher proportion of faceworkers in this age group in $Q$ and therefore probably more men who worked in very dusty conditions but their pneumoconiosis is all very slight.

The 13 men with progressive massive fibrosis (Table 5) were all placed in Category $A$, the earliest degree of P.M.F. and none had advanced disease. The radiograph showed a background of Category 2 in seven men and Category 3 in six men. Eight members of the office staff at the three pits were radiographed and all were placed in Category 0.

\section{Faceworkers}

As in the Durham survey the term " faceworker " is used for men who have at any time worked for six months or more as hewer, coal-cutter, filler, stoneman, deputy, shotfirer, or in a combination of these, such as "composite work" (coal hewing and stonework).

The occupational histories of the faceworkers gave the proportion of time that they spent in each

TABLE 5

NUMBER AND PERCENTAGE OF MEN IN EACH RADIOLOGICAL CATEGORY BY AGE

\begin{tabular}{|c|c|c|c|c|c|c|c|c|c|c|c|c|c|}
\hline \multirow{3}{*}{ Age } & \multicolumn{10}{|c|}{ Radiological Category } & \multirow{3}{*}{ Total } & \multirow{3}{*}{$\begin{array}{l}\% \text { in } \\
\text { Category } 1 \\
\text { and Over }\end{array}$} & \multirow{3}{*}{$\begin{array}{l}\% \text { in } \\
\text { Category } 2 \\
\text { and Over }\end{array}$} \\
\hline & \multicolumn{2}{|c|}{0} & \multicolumn{2}{|c|}{1} & \multicolumn{2}{|c|}{2} & \multicolumn{2}{|c|}{3} & \multicolumn{2}{|c|}{ P.M.F. } & & & \\
\hline & No. & $\%$ & No. & $\%$ & No. & $\%$ & No. & $\%$ & No. & $\%$ & & & \\
\hline \multirow[t]{2}{*}{$\begin{array}{l}15-25 \\
26-35 \\
36-45 \\
46-55 \\
56+\end{array}$} & $\begin{array}{l}435 \\
602 \\
497 \\
391 \\
255\end{array}$ & $\begin{array}{l}99.1 \\
91.5 \\
77.4 \\
60.2 \\
50.1\end{array}$ & $\begin{array}{r}4 \\
50 \\
97 \\
125 \\
121\end{array}$ & $\begin{array}{r}0.9 \\
7.6 \\
15.1 \\
19.2 \\
23.8\end{array}$ & $\begin{array}{r}\overline{5} \\
44 \\
101 \\
91\end{array}$ & $\begin{array}{r}\overline{0.8} \\
6.9 \\
15.5 \\
17.9\end{array}$ & $\begin{array}{l}\bar{Z} \\
4 \\
30 \\
33\end{array}$ & $\begin{array}{l}\overline{-} \\
\overline{0} \\
4.6 \\
6.5\end{array}$ & $\begin{array}{c}\overline{1} \\
3 \\
9\end{array}$ & $\begin{array}{l}\overline{0.2} \\
\overline{0.5} \\
1.8\end{array}$ & $\begin{array}{l}439 \\
658 \\
642 \\
650 \\
509\end{array}$ & $\begin{array}{r}0.9 \\
8 \cdot 5 \\
22 \cdot 6 \\
39.8 \\
49.9\end{array}$ & $\begin{array}{r}\overline{0.9} \\
7.5 \\
20.6 \\
26.1\end{array}$ \\
\hline & 2,180 & $75 \cdot 2$ & 397 & $13 \cdot 7$ & 241 & $8 \cdot 3$ & 67 & $2 \cdot 3$ & 13 & 0.4 & 2,898 & $24 \cdot 8$ & $11 \cdot 1$ \\
\hline
\end{tabular}


TABLE 7

PROPORTION OF TIME SPENT IN VARIOUS TYPES OF FACEWORK AT EACH COLLIERY DERIVED FROM SUBJECTS' OCCUPATIONAL HISTORIES

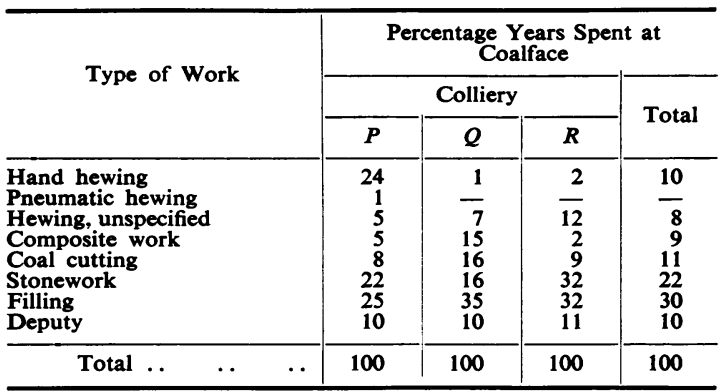

colliery at various jobs (Table 7). Hand hewing had been used extensively in the past in Pit $P$ compared with $Q$ and $R$ and there was practically no pneumatic hewing. Some of the unspecified hewing and composite work may have been by pneumatic pick, although most of it was probably hand work. The large amount of time at filling $(30 \%)$ and stonework $(22 \%)$ relative to coal cutting is consistent with the general use of mechanical cutters. In Pit $Q$ rather more time was spent on composite work than in the other collieries, and deputy work took the same proportion of time in all three.

About $85 \%$ of the faceworkers' years at the face were spent at the colliery in which they were radiographed (Table 8).

Fifty-six per cent. of the men began facework between the ages of 20 and 24 years but $18 \%$ were

TABLE 8

PROPORTION OF FACEWORKERS' YEARS AT FACE SPENT AT THEIR PRESENT COLLIERY

\begin{tabular}{|c|c|c|c|}
\hline Category & $\underset{(\%)}{P}$ & $\stackrel{Q}{\%})$ & $\begin{array}{c}R \\
(\%)\end{array}$ \\
\hline $\begin{array}{c}0 \\
1 \\
2 \\
3 \\
\text { P.M.F. }\end{array}$ & $\begin{array}{l}88 \\
81 \\
82 \\
69 \\
79\end{array}$ & $\begin{array}{r}83 \\
87 \\
81 \\
80 \\
100\end{array}$ & $\begin{array}{r}84 \\
88 \\
81 \\
93 \\
100\end{array}$ \\
\hline Average & 85 & 84 & 85 \\
\hline
\end{tabular}

between 14 and 19 years of age when they started. After 25 years of age the numbers starting facework fall off but a few men go on to facework for the first time up to the age of 45 .

\section{Radiographic Category by Years at Face and Age}

The effect of time at facework on radiological category is shown in Table 9 and Fig. 2. There is an increase in the proportion of men in each category with rise in years at the face, except in the P.M.F. group which comprises only 13 men. After more than 10 years' facework there is a marked rise in the percentage of men in each category, and there are none in category P.M.F. with less than 10 years at facework. Individual collieries (Table 10) show much the same trend but $Q$ has more pneumoconiosis in each 10 -year period than $P$, and $R$ has more still after more than 10 years at facework.

TABLE 10

PERCENTAGE OF PNEUMOCONIOSIS (CATEGORY 1 AND ABOVE) BY COLLIERIES

\begin{tabular}{|c|c|c|c|c|}
\hline \multirow{2}{*}{ Years at Face } & \multicolumn{3}{|c|}{ Colliery } & \multirow{2}{*}{ Total } \\
\hline & $P$ & $Q$ & $\boldsymbol{R}$ & \\
\hline $\begin{array}{r}0 \\
1-10 \\
11-20 \\
21-30 \\
31+\end{array}$ & $\begin{array}{r}5 \\
5 \\
30 \\
45 \\
58\end{array}$ & $\begin{array}{l}10 \\
13 \\
37 \\
52 \\
63\end{array}$ & $\begin{array}{r}5 \\
12 \\
46 \\
55 \\
81\end{array}$ & $\begin{array}{r}6 \cdot 6 \\
10.5 \\
36.9 \\
50 \cdot 1 \\
65.0\end{array}$ \\
\hline
\end{tabular}

When men with pneumoconiosis of Category 2 or more are compared by age and number of years at facework (Table 11), all except six are over 35 years of age and there are only eight men who have done no facework. Ninety-six of these men who are aged 56 years and over have spent more than 30 years at facework. Numbers in each group are rather small but in the two older age groups (46-55 years and 56+) years at facework is more important in increasing category than is age.

\section{Withdrawals}

Withdrawals of men from facework to other work at the same colliery increase with age rather than

TABLE 9

NUMBER AND PERCENTAGE OF MEN IN EACH RADIOLOGICAL CATEGORY BY YEARS AT FACEWORK

\begin{tabular}{|c|c|c|c|c|c|c|c|c|c|c|c|c|c|}
\hline \multirow{3}{*}{$\begin{array}{c}\text { No. of } \\
\text { Years } \\
\text { at } \\
\text { Face }\end{array}$} & \multicolumn{10}{|c|}{ Radiological Category } & \multirow{3}{*}{ Total } & \multirow{3}{*}{$\begin{array}{l}\% \text { in } \\
\text { Category } 1 \\
\text { and Over }\end{array}$} & \multirow{3}{*}{$\begin{array}{c}\% \text { in } \\
\text { Category } 2 \\
\text { and Over }\end{array}$} \\
\hline & \multicolumn{2}{|c|}{0} & \multicolumn{2}{|c|}{1} & \multicolumn{2}{|c|}{2} & \multicolumn{2}{|c|}{3} & \multicolumn{2}{|c|}{ P.M.F. } & & & \\
\hline & No. & $\%$ & No. & $\%$ & No. & $\%$ & No. & $\%$ & No. & $\%$ & & & \\
\hline $\begin{array}{c}0 \\
1-10 \\
11-20 \\
21-30 \\
31+\end{array}$ & $\begin{array}{l}999 \\
589 \\
274 \\
203 \\
115\end{array}$ & $\begin{array}{l}93.4 \\
89.5 \\
63.1 \\
49.9 \\
35.0\end{array}$ & $\begin{array}{l}63 \\
53 \\
96 \\
92 \\
93\end{array}$ & $\begin{array}{r}5 \cdot 9 \\
8 \cdot 1 \\
22 \cdot 1 \\
22 \cdot 6 \\
28 \cdot 3\end{array}$ & $\begin{array}{r}7 \\
15 \\
57 \\
80 \\
82\end{array}$ & \begin{tabular}{r|}
$0 \cdot 7$ \\
$2 \cdot 3$ \\
$13 \cdot 1$ \\
$19 \cdot 7$ \\
$24 \cdot 9$
\end{tabular} & $\begin{array}{r}1 \\
1 \\
4 \\
30 \\
31\end{array}$ & $\begin{array}{l}0 \cdot 1 \\
0 \cdot 2 \\
0 \cdot 9 \\
7 \cdot 4 \\
9 \cdot 4\end{array}$ & $\begin{array}{l}- \\
3 \\
2 \\
8\end{array}$ & $\begin{array}{l}\overline{-} \\
0 \cdot 7 \\
0 \cdot 5 \\
2 \cdot 4\end{array}$ & $\begin{array}{r}1,070 \\
658 \\
434 \\
407 \\
329\end{array}$ & $\begin{array}{r}6 \cdot 6 \\
10 \cdot 5 \\
36 \cdot 9 \\
50 \cdot 1 \\
65 \cdot 0\end{array}$ & $\begin{array}{r}0 \cdot 7 \\
2 \cdot 4 \\
14 \cdot 7 \\
27 \cdot 5 \\
36 \cdot 8\end{array}$ \\
\hline & 2,180 & - & 397 & - & 241 & - & 67 & - & 13 & - & $\overline{2,898}$ & - & - \\
\hline
\end{tabular}


with radiological category (Table 12), except in the small number of men with P.M.F. Six men with P.M.F. over 56 years of age are still at facework, out of a total of only nine men in this group.

Non-faceworkers with Pneumoconiosis.-Many of these men had done a variety of surface work but there was usually a predominant job which lasted for seven years or more. Several men did the same work for many years, e.g., a screener for 37 years or a blacksmith for 53 years. There were 13 screeners and eight blacksmiths with pneumoconiosis, mainly Category 1 , and six bricklayers with Category 1 changes who worked underground for varying periods. Various other occupations above and below ground, such as datal worker, electricians, and pitheap workers, are also represented, but all in Category 1.

TABLE 11

MEN WITH PNEUMOCONIOSIS OF CATEGORY 2 OR MORE BY AGE AND YEARS OF FACEWORK

\begin{tabular}{|c|c|c|c|c|c|c|c|c|c|c|c|c|}
\hline \multirow{3}{*}{ Age } & \multicolumn{10}{|c|}{ Years at the Face } & \multirow{2}{*}{\multicolumn{2}{|c|}{$\begin{array}{c}\text { Average } \\
\text { Total }\end{array}$}} \\
\hline & \multicolumn{2}{|c|}{0} & \multicolumn{2}{|c|}{$1-10$} & \multicolumn{2}{|c|}{$11-20$} & \multicolumn{2}{|c|}{$21-30$} & \multicolumn{2}{|c|}{31 and Over } & & \\
\hline & No. & $\%$ & No. & $\%$ & No. & $\%$ & No. & $\%$ & No. & $\%$ & No. & $\%$ \\
\hline $\begin{array}{r}15-25 \\
26-35 \\
36-45 \\
46-55 \\
56+\end{array}$ & $\begin{array}{l}\overline{-} \\
\overline{2} \\
1 \\
5\end{array}$ & $\begin{array}{l}- \\
1.0 \\
0.7 \\
4.6\end{array}$ & $\begin{array}{l}3 \\
4 \\
5 \\
4\end{array}$ & $\begin{array}{r}\overline{1} \\
0.8 \\
2 \cdot 6 \\
7 \cdot 2 \\
12 \cdot 9\end{array}$ & $\begin{array}{r}\overline{3} \\
22 \\
28 \\
11\end{array}$ & $\begin{array}{l}\overline{4 \cdot 5} \\
11 \cdot 1 \\
23 \cdot 9 \\
21 \cdot 6\end{array}$ & $\begin{array}{l}\overline{ } \\
20 \\
75 \\
17\end{array}$ & $\begin{array}{l}\overline{-} \\
21 \cdot 1 \\
30.9 \\
24.6\end{array}$ & $\begin{array}{l}\bar{Z} \\
25 \\
96\end{array}$ & $\begin{array}{l}\bar{Z} \\
\overline{32 \cdot 1} \\
38 \cdot 4\end{array}$ & $\begin{array}{r}\overline{6} \\
48 \\
134 \\
133\end{array}$ & $\begin{array}{r}\overline{0.9} \\
7.5 \\
22.1 \\
26 \cdot 1\end{array}$ \\
\hline Total .. & 8 & $0 \cdot 7$ & 16 & $2 \cdot 4$ & 64 & $14 \cdot 7$ & 112 & $27 \cdot 5$ & 121 & $36 \cdot 8$ & 321 & $11 \cdot 1$ \\
\hline
\end{tabular}


TABLE 12

TOTAL FACEWORKERS OR FORMER FACEWORKERS BY AGE AND CATEGORY SHOWING NUMBER AND PERCENTAGE WITHDRAWN FROM FACEWORK FOR AT LEAST SIX MONTHS AT TIME OF SURVEY BUT STILL EMPLOYED AT THE COLLIERY*

\begin{tabular}{|c|c|c|c|c|c|c|c|c|c|c|c|c|c|}
\hline \multirow{3}{*}{$\begin{array}{l}\text { Age } \\
\text { in } \\
\text { Years }\end{array}$} & & \multicolumn{10}{|c|}{ Radiological Category } & \multirow{2}{*}{\multicolumn{2}{|c|}{ Totals }} \\
\hline & & \multicolumn{2}{|c|}{0} & \multicolumn{2}{|c|}{1} & \multicolumn{2}{|c|}{2} & \multicolumn{2}{|c|}{3} & \multicolumn{2}{|c|}{ P.M.F. } & & \\
\hline & & No. & $\%$ & No. & $\%$ & No. & $\%$ & No. & $\%$ & No. & $\%$ & No. & $\%$ \\
\hline $\begin{array}{l}26-35 \\
36-45 \\
46-55 \\
56+\end{array}$ & $\begin{array}{l}\text { Faceworkers } \\
\text { Withdrawn } \\
\text { Faceworkers } \\
\text { Withdrawn } \\
\text { Faceworkers } \\
\text { Withdrawn } \\
\text { Faceworkers } \\
\text { Withdrawn }\end{array}$ & $\begin{array}{r}376 \\
20 \\
320 \\
38 \\
267 \\
83 \\
167 \\
80\end{array}$ & $\begin{array}{l}\overline{5 \cdot 3} \\
\overline{11 \cdot 9} \\
\overline{31 \cdot 1} \\
\overline{4 \overline{7 \cdot 9}}\end{array}$ & $\begin{array}{r}40 \\
3 \\
80 \\
15 \\
107 \\
28 \\
106 \\
36\end{array}$ & $\begin{array}{l}\overline{7 \cdot 5} \\
\frac{\overline{18 \cdot 8}}{2 \overline{26 \cdot 2}} \\
\overline{34 \cdot 0}\end{array}$ & $\begin{array}{r}5 \\
42 \\
3 \\
100 \\
36 \\
87 \\
40\end{array}$ & $\begin{array}{l}\bar{Z} \\
\overline{7 \cdot 1} \\
\frac{\overline{36} \cdot 0}{\overline{46 \cdot 0}}\end{array}$ & $\begin{array}{r}-\bar{c} \\
\frac{4}{30} \\
7 \\
32 \\
11\end{array}$ & $\begin{array}{l}\bar{Z} \\
\bar{Z} \\
\overline{23 \cdot 3} \\
\overline{34 \cdot 4}\end{array}$ & $\begin{array}{l}1 \\
- \\
3 \\
3 \\
9 \\
3\end{array}$ & $\begin{array}{l}\bar{Z} \\
\bar{Z} \\
\overline{100 \cdot 0} \\
\overline{33 \cdot 3}\end{array}$ & $\begin{array}{r}422 \\
23 \\
446 \\
56 \\
507 \\
157 \\
401 \\
170\end{array}$ & $\begin{array}{l}\overline{5 \cdot 5} \\
\frac{-}{12 \cdot 6} \\
\frac{31 \cdot 0}{4 \overline{2 \cdot 4}}\end{array}$ \\
\hline
\end{tabular}

* No information is available concerning men who have left the pit altogether.

Pulmonary Tuberculosis

Thirty-five men were referred to chest clinics for further observation (Table 13). Ten men from

TABLE 13

MEN REFERRED TO CHEST CLINICS FROM THE SURVEY

\begin{tabular}{|c|c|c|c|c|c|c|}
\hline \multirow{3}{*}{ Colliery } & \multicolumn{5}{|c|}{ Pulmonary Tuberculosis } & \multirow{3}{*}{$\begin{array}{l}\text { Other } \\
\text { Chest } \\
\text { Conditions }\end{array}$} \\
\hline & \multicolumn{2}{|c|}{ Radiologically } & \multicolumn{2}{|c|}{ Sputum } & \multirow{2}{*}{$\begin{array}{c}\text { Did } \\
\text { not } \\
\text { Attend }\end{array}$} & \\
\hline & Active & Inactive & Positive & Negative & & \\
\hline $\begin{array}{l}P \\
Q \\
R\end{array}$ & $\begin{array}{l}4 \\
2 \\
1\end{array}$ & $\begin{array}{l}6 \\
5 \\
2\end{array}$ & $\begin{array}{l}3 \\
0 \\
0\end{array}$ & $\begin{array}{l}7 \\
3 \\
1\end{array}$ & $\begin{array}{l}0 \\
4 \\
2\end{array}$ & $\begin{array}{r}3 \\
10 \\
2\end{array}$ \\
\hline Total & 7 & 13 & 3 & 11 & 6 & 15 \\
\hline
\end{tabular}

colliery $P$, seven from $Q$, and three from $R$ had pulmonary tuberculosis and the remaining 15 men had pulmonary or cardiac conditions requiring investigation. Of the 20 men with pulmonary tuberculosis, seven were thought to have active disease on purely radiological grounds, and the remainder to require further observation. Three men, all at colliery $\boldsymbol{P}$, had sputa positive for tubercle bacilli, 11 had negative sputa, and six men failed to attend for investigation.

The proportion of men with radiological signs of

TABLE 14

MEN SHOWING RADIOLOGICAL EVIDENCE OF PAST PULMONARY TUBERCULOSIS BY AGE AND COLLIERY (ALL CATEGORIES)

\begin{tabular}{|c|c|c|c|c|c|c|}
\hline \multirow{3}{*}{$\begin{array}{l}\text { Age } \\
\text { in } \\
\text { Years }\end{array}$} & \multicolumn{6}{|c|}{ Colliery } \\
\hline & \multicolumn{2}{|c|}{$P$} & \multicolumn{2}{|c|}{$Q$} & \multicolumn{2}{|c|}{$R$} \\
\hline & No. & $\%$ & No. & $\%$ & No. & $\%$ \\
\hline \multirow[t]{2}{*}{$\begin{array}{c}15-25 \\
26-35 \\
36-45 \\
46-55 \\
56+\end{array}$} & $\begin{array}{r}3 \\
8 \\
6 \\
8 \\
15\end{array}$ & $\begin{array}{l}3.0 \\
5.0 \\
2.9 \\
3.3 \\
6.8\end{array}$ & $\begin{array}{r}\overline{5} \\
4 \\
14 \\
9\end{array}$ & $\begin{array}{l}\overline{1.7} \\
1.5 \\
5.8 \\
5.6\end{array}$ & $\begin{array}{l}1 \\
4 \\
2 \\
5 \\
5\end{array}$ & $\begin{array}{l}0.5 \\
2.0 \\
1.2 \\
3.0 \\
3.9\end{array}$ \\
\hline & 40 & $4 \cdot 3$ & 32 & 2.9 & 17 & 1.9 \\
\hline \multicolumn{2}{|c|}{$\begin{array}{l}\text { Standardized } \\
\text { rates }\end{array}$} & 3.9 & - & 3.0 & - & $2 \cdot 1$ \\
\hline
\end{tabular}

past pulmonary tuberculosis (excluding primary complex) follows the same order, being highest in colliery $P$ and lowest in $R$ (Table 14).

\section{Non-attenders}

Five-hundred-and-two men $(14.8 \%)$ did not attend for radiography but 348 of them were interviewed personally (Table 15 ). Sufficient information

TABLE 15

MEN NOT RADIOGRAPHED BUT VISITED BY A SOCIAL WORKER

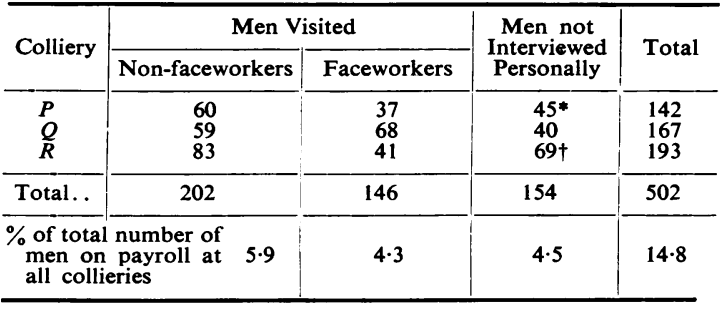

* 22 of these men were under 21 years of age.

$\dagger 36$ of these men were under 21 years of age.

was gained from visiting these men to place them in faceworker or "non-faceworker" groups, and $202(5.9 \%)$ of the latter failed to attend compared with $146(4 \cdot 3 \%)$ faceworkers. It was unfortunately not always possible to obtain the age of nonattenders who were not interviewed personally, but for those whose age was known the number in age group 15-25 years was relatively large, possibly because some men who were on the colliery books were in fact doing national service. In men aged 26 and over those not attending had a similar age structure to those radiographed.

\section{Stonework and Radiological Category}

An attempt was made to determine whether working in stone for long periods has a greater tendency to produce radiological changes than similar periods 
of work in coal only, or in coal and stone. No difference in the prevalence of pneumoconiosis was found for men who have worked predominantly in stone and were therefore presumably exposed to more silica than coal-getters or composite workers (mixed coal and stoneman). As men become older the number who continue to work in stone exclusively decreases, while coal-getters tend to continue as such and it is possible that complete withdrawal from the industry affects stoneworkers more because of advanced pneumoconiosis (P.M.F.) or silicosis but there is no information about men who have left these pits.

\section{Discussion}

The value of prevalence studies of coal-miners' pneumoconiosis has recently been discussed by Cochrane, Davies, Chapman, and Rae (1956) who point out that the prevalence rate measures the size of the problem, and is a necessary first step in the measurement of attack and progression rates, although similar prevalence rates may represent very different attack and fatality rates. The present investigation was made to determine how common certain radiological abnormalities were in Northumbrian miners compared with Durham miners and miners elsewhere in Britain. In dealing with pneumoconiosis as a clinical problem in this area such prevalence studies have considerable practical value in bringing the problem into perspective and in allaying fears among the miners. The overall prevalence of pneumoconiosis of Category 2 or more in the Durham collieries (1950-51) was $22 \%$ compared with $11 \%$ in the Northumbrian collieries (1953-54), but it may be misleading to compare these figures if the age structure of the group of men studied is not taken into account. In fact the age distribution of men radiographed in Durham was generally similar to that of the Northumbrian miners except in the 56-plus group in which there were rather more men in Northumberland (17\%) than in Durham $(13 \%)$. This may be a result of less pneumoconoisis and a very small amount of disabling P.M.F. in Northumberland. These figures suggest that if the age structures of working miners in the two counties had been identical the difference in amount of pneumoconiosis would have been accentuated.

In north-east England the natural progression of a miner's work is from a short period at bank as a youth through datal work underground to facework, as a hewer, cutter, filler, or stoneworker. In middle age or later a miner returns to datal work or to bank as age or infirmity makes itself felt. For this reason it is logical to group together men who have at any time done six months or more at facework (which may include men actually doing surface or datal work at the time of the survey) rather than to divide men into surface and faceworkers on the basis of their present jobs.

Thus Cochrane et al. (1956) show that not only is there a higher prevalence of pneumoconiosis, particularly of P.M.F., in men working at the surface at the time of the investigation but that the proportion is higher still in ex-miners living in the same town. We have not been able to include ex-miners in our surveys but it seems reasonable to restrict arbitrarily the scope of the survey to those men actually employed at the pit at the time of the survey so far as they can be defined.

The proportion of men radiographed was $85 \%$ compared with $89 \%$ in Durham collieries. The same difficulty was experienced in both areas in determining with any degree of exactness the number of men actually employed at the collieries even when the pay roll was taken as a guide. As a result a number of men at each colliery are untraced because of insufficient information in the records or because they were casually employed, but it is likely that most of the regularly employed men were accounted for.

The impression obtained from out-patient work and compensation figures that there is less radiological pneumoconiosis in Northumberland than in Durham is confirmed by this survey. The average prevalence of all categories of pneumoconiosis in the men radiographed at these three Northumberland collieries is about $25 \%$ compared with $32 \%$ in four Durham collieries (McCallum and Browne, 1955), and in radiological categories 2 and over, the proportion in Northumberland $(11 \%)$ is half that in Durham $(22 \%)$. Progressive massive fibrosis in Northumberland is even less frequent in proportion, being about a fifth of that in Durham (Fig. 3).

These differences in prevalence in the two coalfields may result from different methods of working and seams worked, but two other factors might affect the recorded prevalence of pneumoconiosis in the Northumbrian coalfield. These factors both result from the wide use of mass miniature radiography (M.M.R.) in Northumberland where units have visited nearly all the pits at least once during the last few years. In Durham the four pits had not been visited by any radiography unit before our survey.

First, the proportion of men who attended for radiographic examination was $85 \%$ which is about $4 \%$ less than in the Durham survey. If there were more pneumoconiosis amongst the non-attenders than amongst those radiographed, then the true prevalence would be higher. In Northumberland, insufficient time was spent at the collieries and if the radiographic unit had been available for longer 


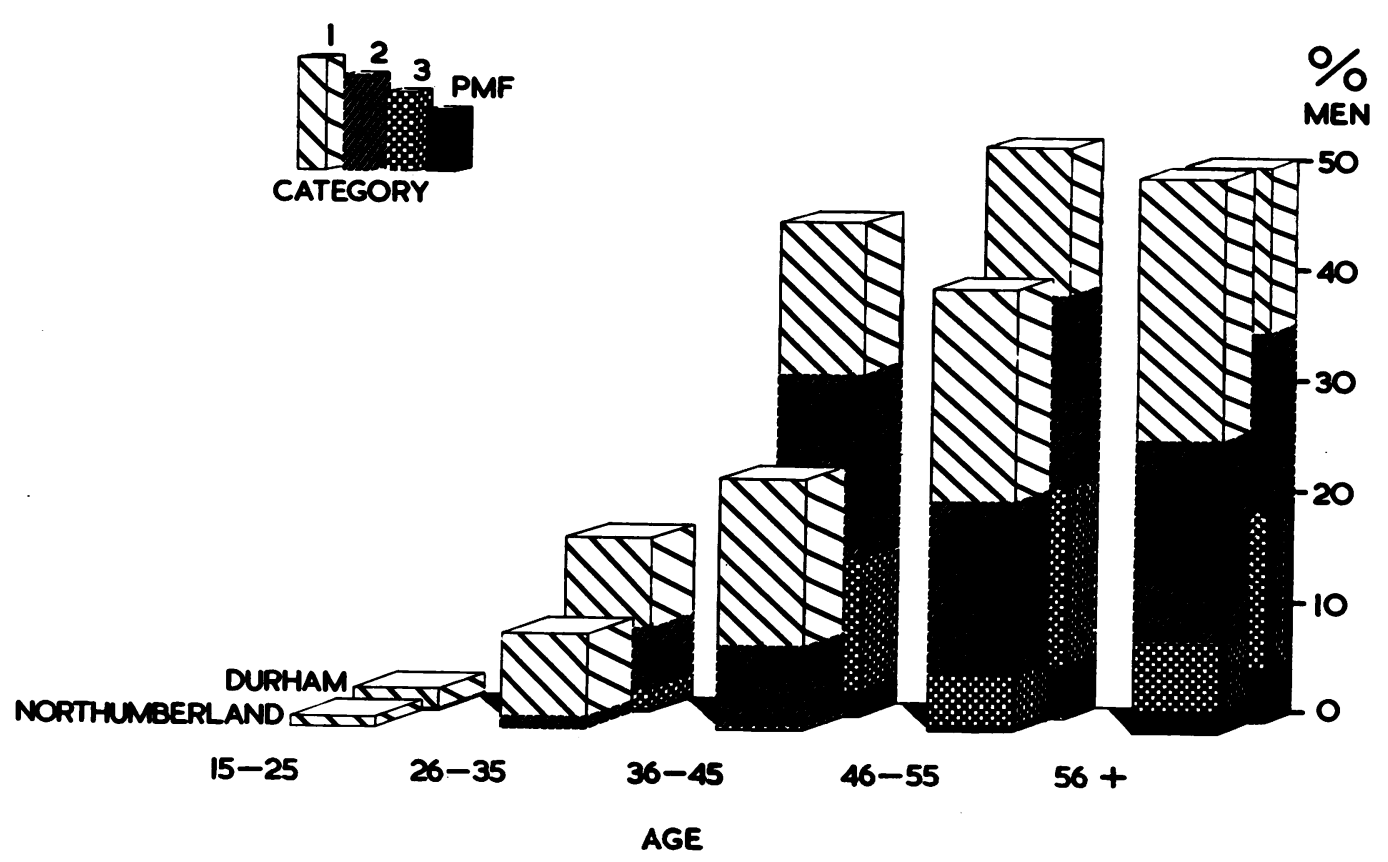

FIG. 3.-Prevalence of pneumoconiosis in four collieries in Durham and three collieries in Northumberland showing the radiological categories in each age group.

periods the number of non-attenders might have been appreciably less. But pneumoconiosis was not such a live issue amongst the Northumbrian miners as it was in Durham, perhaps because of a true smaller prevalence and of some degree of apathy at these collieries as a result of previous mass radiography. Secondly, the earlier visits of an M.M.R. unit could have led to the withdrawal of a substantial number of men with pneumoconiosis, especially those with Category 3 and with P.M.F. In general, however, the response to M.M.R. was poor and the recorded prevalence very low; and in the five years before these surveys only 11 men from these three Northumbrian pits were known to the National Coal Board (N.C.B.) as certified cases of pneumoconiosis. Only perhaps two-thirds of boarded cases are known to the N.C.B. so that if all the men boarded had been men with P.M.F. the number in that category would be more than doubled, but the proportion would still be only half that of Durham.

If all the men on the pay roll who were not radiographed (Table 15) are assumed to have normal lungs then $21.1 \%$ of all the men had some pneumoconiosis; if, on the other hand, half of the men not radiographed had pneumoconiosis of any category, then $27 \%$ of all the men are affected. About half these men not examined were probably faceworkers and if it is assumed that half of them have pneumo- coniosis then the estimated true prevalence is $24 \%$.

The exception to a generally much lower prevalence of radiological pneumoconiosis in Northumberland compared with Durham is in Category 1 where the proportion $(13.7 \%)$ is actually higher than in Durham $(10 \cdot 3 \%)$.

In Durham the majority of the men certified by the Pneumoconiosis Panel in 1951-53 are over 35 to 40 years, whereas in Northumberland the level is about a decade higher at $\mathbf{4 5}$ to $\mathbf{5 0}$ years, so that not only is there less pneumoconiosis in Northumberland, but it comes to the notice of the Pneumoconiosis Panel rather later. In the two years (1951-1952) immediately before the survey six men were certified with pneumoconiosis from the three pits. This number rose to 57 in 1953-54 presumably as a direct result of the survey, as in the rest of Northumberland the corresponding rise over the same period was only from 95 to 126 men certified.

In the four Durham collieries surveyed in 1950-51 there was a tendency for the number of men in each category of pneumoconiosis to become stable at a certain level after a period of time; withdrawal from facework was associated with advancing age and particularly with P.M.F., and length of time at facework was associated with an increase in prevalence of radiological pneumoconiosis. The effect of facework became demonstrable after about 35 years of 
age or 10 years at the face. Allowing for a difference in age at which heavy dust exposure began, there was a remarkable similarity between the proportion of men at different ages with pneumoconiosis in Durham and South Wales.

In these three Northumbrian collieries the percentage of miners with pneumoconiosis at age 20 years is small, as in Durham, and both begin to rise between 20 and 30 years of age (Fig. 4). The rise in Northumberland is progressively later than in Durham taking about five years longer to reach $10 \%$, six years longer to reach $20 \%$, and about 13 years longer to reach $40 \%$. The difference is even more marked between Northumberland and the Rhondda Fach. This suggests that the Northumbrian mines have been much less dusty than either Durham or South Wales, or that there is some qualitative difference in the dust. At 60 years of age, however, the curves meet because the levels in Durham and the Rhondda Fach remain much the same after the age of $\mathbf{4 0}$ while that in Northumberland continues to rise. This high figure in Northumberland is largely due to the greater proportion of men in Category 1 than in Durham, for, if Category 2 and over is taken, Northumberland is $9 \%$ lower than Durham after 55 years of age (Fig. 3). The graph for Northumberland is practically linear (Fig. 4) even when Category 1 is excluded. The reason for this may be that withdrawals from the industry have been random and unrelated to the lung radiograph because most of the pneumoconiosis was not disabling.

Differences in age structure of the men at each colliery do not much affect the overall prevalence of pneumoconiosis. Although colliery $P$ has fewer young men and more older men than $R$, they are very similar as regards prevalence of pneumoconiosis. In Northumberland withdrawals from facework increase with age, but in men with P.M.F. the numbers are so small that it is difficult to say that withdrawal has occurred for any reason other than age also. Six men with P.M.F. over 56 years of age are still working at the face but all the P.M.F. is in Category $A$ from which disability is often slight. On the other hand, men in Categories $B-D$ may well have left mining altogether because of more severe disability.

There are too few men under 35 years of age with pneumoconiosis to draw any conclusions about the importance of age or years at the face, but for the older men number of years at facework is more significant in increasing the radiological category than years of age.

Among the non-faceworkers with pneumoconiosis, screeners and blacksmiths have more men than any other group. Although most of these men had only

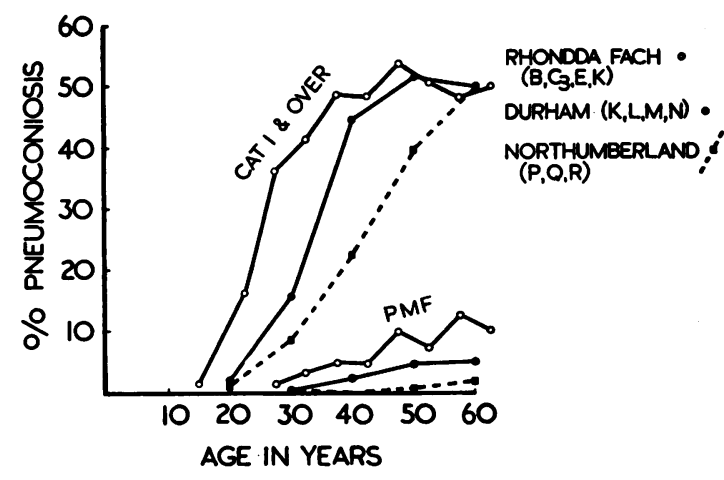

Fig. 4.-Percentage of pneumoconiosis of radiological category 1 and over in the Rhondda Fach (four collieries), Durham (four collieries), and Northumberland (three collieries). Progressive massive fibrosis is also shown separately. The Rhondda Fach figures refer to all underground workers while the Durham and Northumberland figures refer to all men employed at the collieries.

Category 1 changes it is clearly desirable to investigate and control the dustiness of those jobs.

The marked difference in prevalence of radiological pneumoconiosis in the adjacent coalfields $0^{\circ}$ Durham and Northumberland may be explained $t$ differences in working methods, which depend larg ${ }^{*}$ on the type of coal and ventilation. In Northu brian collieries hand picks were replaced $t$ mechanical cutters rather than by pneumatic pick as the coal is hard. In Durham, where the coal is more friable, pneumatic picks are common and bord-and-pillar work, in which efficient ventilation across the working area is difficult to achieve, is traditional. It has been shown, however, that in Durham dustiness relates to low seam height and rank of coal and not to method of working (Hall, 1956), and it is significant that in the deeper Durham pits nearly half the seams worked are less than $2 \frac{1}{2} \mathrm{ft}$. thick.

\section{Summary}

Prevalence data for radiological pneumoconiosis of coal-miners in Northumberland are given for the first time. Large (12 in. by 15 in.) radiographs of the chest were taken of 2,898 men, comprising $85 \%$ of the workers at three pits. Nearly $25 \%$ of the men had pneumoconiosis of radiological category 1 or more, and $11 \%$ had pneumoconiosis of category 2 or more. Progressive massive fibrosis was found in only 13 men $(0.5 \%)$ and was all early (category $A$ ).

The wide use of mass miniature radiography in the same area for several years before this survey probably did not affect these figures.

Compared with the results of similar surveys in four Durham collieries there is much less pneumoconiosis of radiological category 2 or more i, 
Northumberland but there is about $5 \%$ more category 1 pneumoconiosis. The Northumbrian pits are found to have only a fifth of the progressive massive fibrosis found in Durham.

Prevalence of pneumoconiosis in Northumberland reaches the same levels as in Durham between five and 13 years later, and much later than in the Rhondda Fach, but at 60 years of age the prevalence is the same in all three areas. This may be because there is less disabling pneumoconiosis in Northumberland.

Pneumoconiosis of category 1 and occasionally of category 2 was observed amongst blacksmiths and screeners, who had done less than six months on facework, suggesting that the dustiness of these jobs requires control.

It is probable that more friable coal and a high proportion of low seams worked in Durham compared with Northumberland are the most important factors in the difference in prevalence of pneumoconiosis in the two areas.

Acknowledgments are due to the following:-Professor R. C. Browne and Dr. G. L. Leathart of the Department of Industrial Health, University of Durham, who assisted in carrying out the surveys and in viewing the films; the Regional Hospital Board of Region No. 1, and the Newcastle M.M.R. Unit; Dr. G. Hurrell, its medical director who also took part in reading films; the National Coal Board for a grant towards the expense of this survey, and Dr. A. Roberts, Area Medical Officer of the Northern (Northumberland and Cumberland) Division; the National Union of Mineworkers (Northumberland); Mrs. Clare Angley who followed up non-attenders and Mrs. D. Weightman for the tables and figures, both of whom are members of the Department of Industrial Health.

\section{REFERENCES}

Cochrane, A. L., Davies, I., and Fletcher, C. M. (1951), Brit. J. industr. Med., 8, 244.

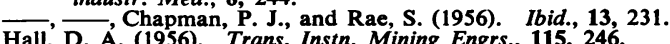

Hall, D. A. (1956). Trans. Instn. Mining Engrs., 115, 246.

Hugh-Jones, P., and Fletcher, C. M. (1951). Medical Research Council Memorandum No. 25. H.M.S.O., London.

Hume, Sir W. E. Personal communication.

International Labour Office (1953). Third International Conference of Experts on Pneumoconiosis, Sydney, 1950. International Labour Office, Geneva.

McCallum, R. I., and Browne, R. C. (1955). Brit. J. industr. Med., 12, 279.

Ministry of Fuel and Power. Digests of Pneumoconiosis Statistics, 1950-1954. H.M.S.O., London. 